\title{
Land Use Changes within the Bogoso-Prestea Gold Concession, South West Ghana*
}

\author{
E. E. Duncan, J. S. Kuma and S. Frimpong
}

Duncan, E. E. Kuma, J. S. and Frimpong, S. (2008), "Land Use Changes within the Bogoso-Prestea Gold Concession, South West Ghana”, Ghana Mining Journal, pp. 1 - 8.

\begin{abstract}
Mining activities have existed in the Bogoso-Prestea area for over a century. The high demand for gold has led to intense mining activities in the area and has resulted in land use changes. This study evaluated a total area of 4379.93 ha within the Bogoso-Prestea Gold Concession that has experienced land use change due to mining using estimation of areas and analysis of land use flows over a period of twenty years ie.1986 - 2006. Results from the study revealed that mining increased in land coverage from 4.69 ha in 1986 to 530.84 ha in 2006, an increase to $12.1 \%$ of the study area. Settlements increased to $4.95 \%$ in 2006 as compared to $0.41 \%$ in 1986, showing a significant rural migration primarily due to mining. Agricultural land use reduced from $97.8 \%$ in 1986 to $82.7 \%$ in 2006 . The study also revealed that land use due to mining increased by only $0.67 \%$ between 1996 and 2006 and if this trend continues, then land use due to mining under the prevailing conditions might not introduce any significant increment between 2006 and 2016.
\end{abstract}

\section{Introduction}

Gold mining activities have existed in the BogosoPrestea and their surrounding areas for over a century. These activities have intensified within the last twenty years due to the high demand for gold coupled with the promulgation of the Ghana Mining and Mineral laws 1986, which promoted largescale capital investment (Sraku-Lartey, 1993). As a result of the relatively low cost of mining surface ore compared to underground mining, most mining companies such as Golden Star Resources Bogoso Prestea Limited (GSRBPL) are increasingly focusing on surface mining. Small-scale miners have also been exploiting surface ores since the inception of gold mining in the area. These surface mining activities have directly affected the environment, especially land. Competition for the use of land has intensified due to the increase in population and the different uses to which land is put by individuals and communities. Surface mining is an additional pressure on land, because it has the tendency to affect the land and communities negatively, if not managed in an environmentally sustainable way.

One of the important processes for monitoring and managing natural resources and urban development, including land, is change detection, because it provides a means of identifying differences in the state of an object or phenomenon at different times (Singh, 1989). Change detection is useful in such diverse applications as land use analysis, monitoring shifting cultivation, assessment of deforestation, study of changes in vegetation phenology, seasonal changes in pasture production, dam- age assessment, crop stress detection, disaster monitoring, day/night analysis of thermal characteristics as well as other environmental changes (Singh, 1989).

According to Macleod and Congalton (1998), four aspects of change detection are important for monitoring natural resources. These are: detecting that changes have occurred, identifying the nature of the change, measuring the aerial extent of the change and assessing the spatial pattern of the change. In order to understand the dynamics of any study area it is very important to consider the historic aspects as well. Finding patterns in the formation of land use changes might give valuable clues to planners. When no other data is available for this kind of analysis, one solution is to use remote sensing imagery as the primary data source; and Geographic Information Systems (GIS) technology can play a key role by providing a framework for spatial analysis of remote sensing data (Bahr, 2001; Donnay et al., 2001). The basic premise in using remotely sensed data for change detection is that changes in land cover result in changes in radiance values which can be remotely sensed.

This study seeks to map and evaluate areas that have experienced land use changes over a 20 -year period using remotely sensed data and GIS within the GSRBPL concession in order to highlight land use flows.

\section{Physiography of the Bogoso-Prestea Concession}

The Bogoso-Prestea concession is located on the western margin of the Ashanti Belt in South-

* Manuscript received June 23, 2008

Revised version accepted July 24, 2008 
Western Ghana. The GSRBPL mine is located near Bogoso, a town in the Wassa West District (see Fig. 1). The mine occupies a $100 \mathrm{~km}^{2}$ area and lies entirely within the Ankobra River basin. It stretches between latitudes $5^{\circ} 29^{\prime} \mathrm{N}$ and $5^{\circ} 37^{\prime} \mathrm{N}$ and longitudes $1^{\circ} 59^{\prime} \mathrm{W}$ and $2^{\circ} 11^{\prime} \mathrm{W}$.

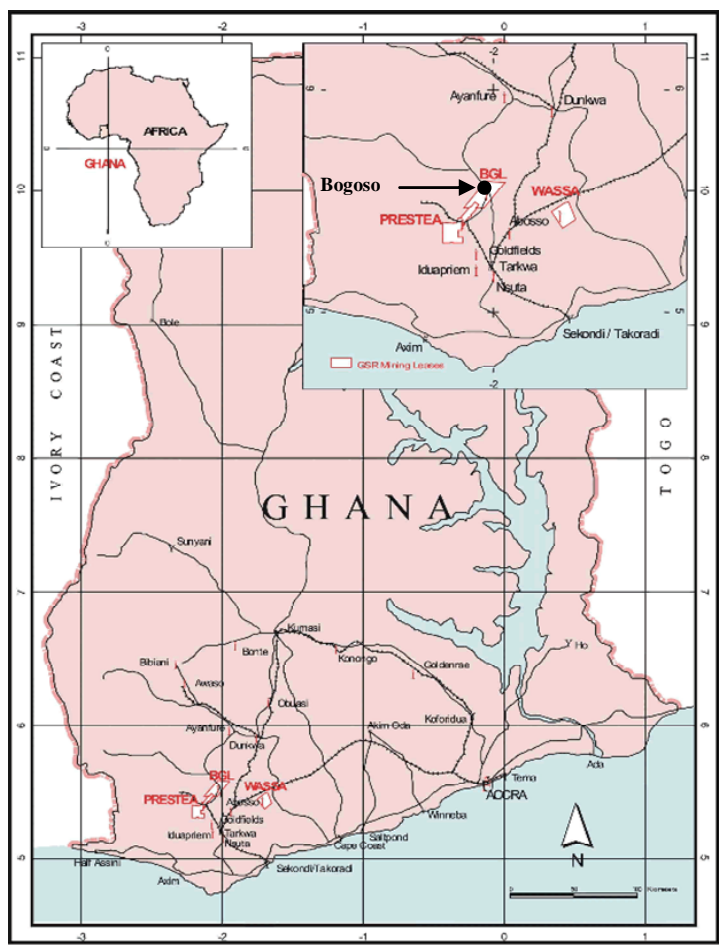

Fig 1 Map of Ghana: Insert, an Enlargement of the BGL Concession Area

The study area is located in the central portion of the GSRBPL concession where different land use categories have been identified totalling $43.8 \mathrm{~km}^{2}$ (4 379.93 ha.). The study area was originally primarily forest but now consists of secondary forest of varying age and quality as a result of timber harvesting, agricultural practices and small-scale mining. Other minor economic activities such as charcoal burning, fire-wood gathering, palm wine tapping, distillation of local gin and harvesting of cane for basket weaving have been identified in the study area. The predominant land use before GSRBPL took over the concession for large-scale mining was wildlife habitat and minor commercial subsistence uses of secondary forest, swamp and bush. Some of these areas were located on the main gold mineralisation zone and served as sites for galamsey activities.

Rainfall gradually increases from March and attains its maximum often in June and sometimes in May or July. It then breaks off until September when it starts again peaking in October, resulting in a bimodal pattern each year. The annual average rainfall recorded by the GSRBPL meterological department between 1986 and 2006 is $1750 \mathrm{~mm}$.
Topography of the study area is generally gently undulating with elevations ranging between $75 \mathrm{~m}$ and $150 \mathrm{~m}$ above sea level. The area is bound on the east by a range of hills that rise to about $210 \mathrm{~m}$ above sea level with slope angles between $20^{\circ}$ and $60^{\circ}$. The land surface is characterised by ditches, trenches and a series of tension cracks, probably due to previous mining activities in the area.

\section{Data Acquisition, Processing, Valida- tion and Analysis}

\subsection{Data Acquisition and Processing}

Rectified orthophotographs for 1986 and 1996 compiled by AAMSurveying and Mapping Consultants at 1:10 000 and 1:25 000 scales respectively were obtained from the Survey department of GSRBPL. The 2006 aerial photographs were obtained as part of GSRBPL's project in order to assess current and future land use changes due to mining within the Bogoso-Prestea concession. The aerial photographs covered an area of $137 \mathrm{~km}^{2}$.

The 2006 aerial photographs were rectified by establishing ground controls at vantage points by employing the Static GPS Survey method. This was carried out by using two GPS receivers mounted at two (2) reference stations for differential GPS. Three (3) roving receiver GPS were then mounted at the points to be geo-referenced. Measurements were taken by staying at the station for about 30 minutes. Post-processing of the measured points was undertaken followed by adjustment to obtain the xyz coordinates of the points using Spectrum Survey Software 3.30. These ground controls were acquired to orient the aerial photographs to known coordinates and ground features. The positions of the points with measured coordinates on the aerial photographs were assigned these coordinates in a process called georeferencing. Normally, these positions are features that can be clearly seen on the photograph. Preferred features are road intersections, building corners, man holes etc. Ideally, these features should be at the corners of the image. Once the corners of the images are geo-referenced the whole image becomes geo-referenced. The aerial photographs were scanned using a laser scanner with ALTEXIS Software to produce continuous-tone, digital raster images (mosaic) of the study area.

Digital Terrain Models (DTM) were created using Triangulated Irregular Network (TIN) using the Delaunay approach (Chen and Guevara, 1987). The height of any point in the study area was obtained from interpolated points created from the DTM. Finally, the raster images were overlaid with the DTM based on ground coordinates so that image displacement could be removed. The results are accurate, rectified raster images of the aerial 
photograph. Unlike an aerial photograph, a rectified image has a uniform scale and as such measurements can be directly made on it. The rectified image is a map and can serve as a base map. The final accuracy of the mosaic was determined by overlaying the ortho-rectified mosaic on the BGL mining plan and it was found to be $1 \mathrm{~m}$. The maps prepared from the aerial photograph images were imported into ArcGIS domain through digitisation. The features were extracted either as polygons or as lines. The coverage was cleaned and edited for dangles, label errors and off-shoots and undershoots to produce an ortho-photograph of the study area. This ortho-photograph was used in the classification of land use and land cover types in the study area using ArcGIS software. Photographic elements like colour, tone, texture, size and pattern along with feature associations were used as interpretation keys for demarcating different land use and land cover categories. Fig. 2 shows the process involved in creating an ortho-photograph.

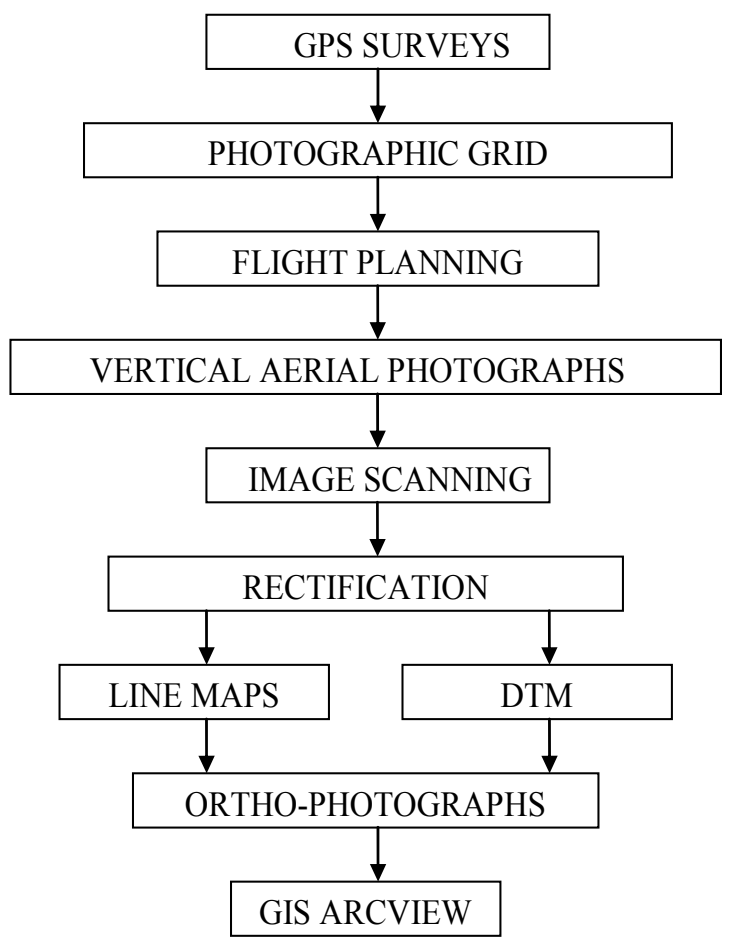

Fig. 2 Process of Creating Digital OrthoPhotographs

The following land use categories were identified and delineated in the study area:

- Settlement features include built up areas (towns and villages) and buildings for industrial, commercial, institutional and recreational use. Part of Bogoso township, Dumasi village, Mine Plant, Offices and residential areas were considered under this category.
- $\quad$ Pit features were made up of all major mine pits and thirteen (13) other minor pits within the study area. These features exclude mined-out areas that have been rehabilitated. Among the major pits are MarluBogoNorth, Dumasi and Chujah.

- Waste Dump features include land used for mine waste rock dumps, topsoil dumps and liquid waste dumps. The four main waste material dumps are Marlu-BogoNorth Waste Dump, Dumasi Waste Dump, Chujah Waste Dump (where both rock waste and topsoil are dumped) and the Tailings Storage Facility (TSF) for storing liquid waste. Like the pits, dump features exclude areas that have been re-vegetated.

- Agricultural features refer to land put to agricultural use and comprise both food and cash crops. Agricultural land was further categorised as rubber plantation, coffee plantation and others. Others refer to lands used for cultivation of cocoa, oil palm, vegetables, food crops, etc. and fallow land. These features are the major land use activities in the study area, and occupy large geographical areas.

- Road line feature refers to both public and mine haul roads and their widths were estimated to be $6 \mathrm{~m}$ and $10 \mathrm{~m}$ respectively.

Figs. 3 to 5 show the maps of processed images of the study area in Ghana National Grid System (metric) using ArcGIS 9.0 for the years 1986, 1996 and 2006. It is significant to note the presence of the large coffee plantation in Figs. 3 and 4. This plantation was no longer under cultivation by 2006 with a corresponding rise in mine developments as evidenced in Fig. 5.

\subsection{Data Validation}

Data validation was carried out to confirm the data employed by conducting ground surveys of selected polygons at the same time the vertical aerial photographs were taken. None of the polygons obtained in 1986 was validated because no ground surveys were conducted. The accuracy of any spatial data may be regarded as the difference between a recorded value (measurement or observed) and its true value (Bannister and Raymond, 1992). Table 1 is the validation results of some features from the 1996 and 2006 images and shows the difference in area between the polygons digitised from aerial photographs and ground surveyed polygons of the same area. These differences can be attributed to error due to digitising and also to some minor distortions such as shadows of trees which tend to increase or decrease the polygon size. 


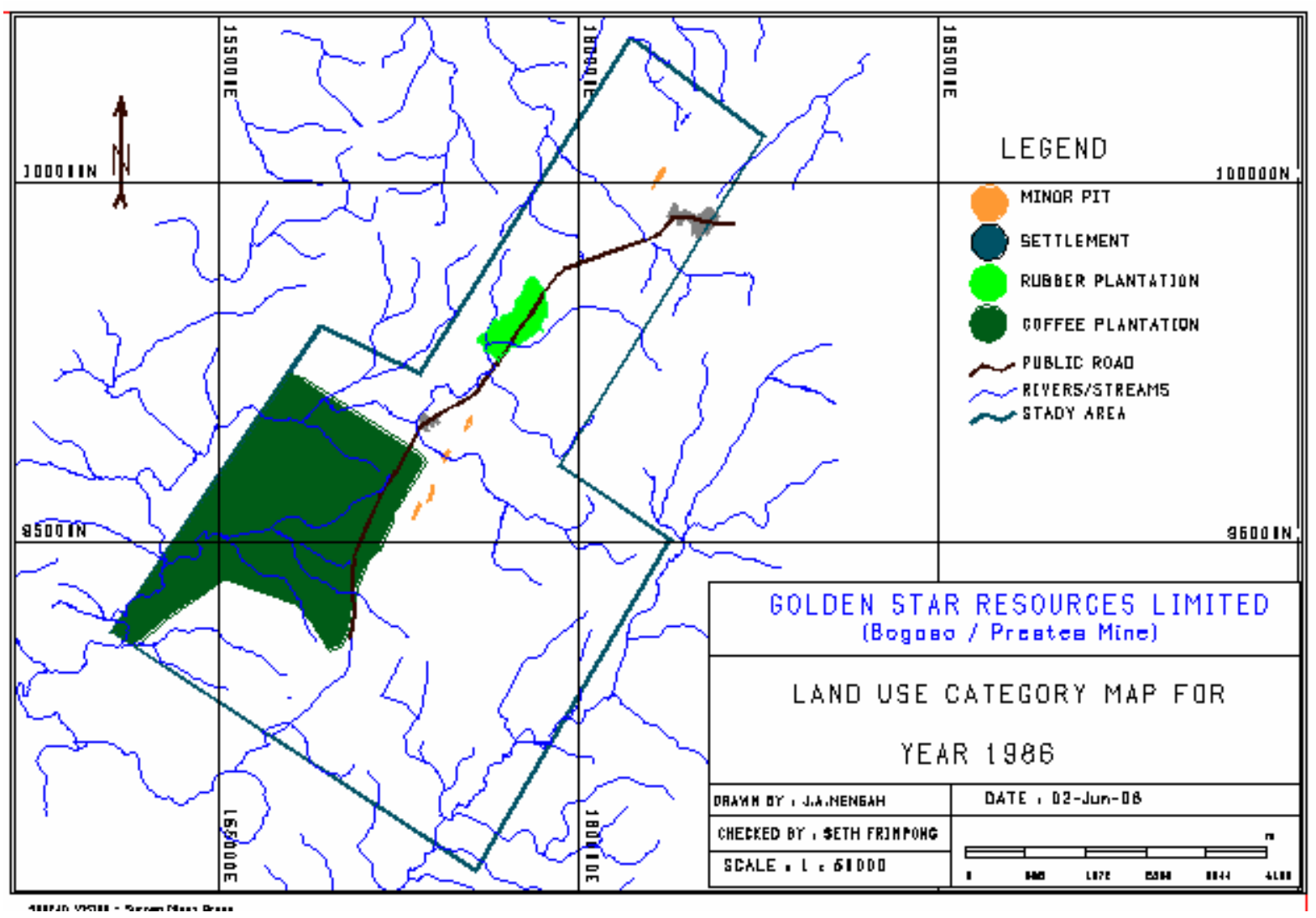

Fig. 3 Land Use Map of Study Area in 1986 at a Scale of 1: 50000

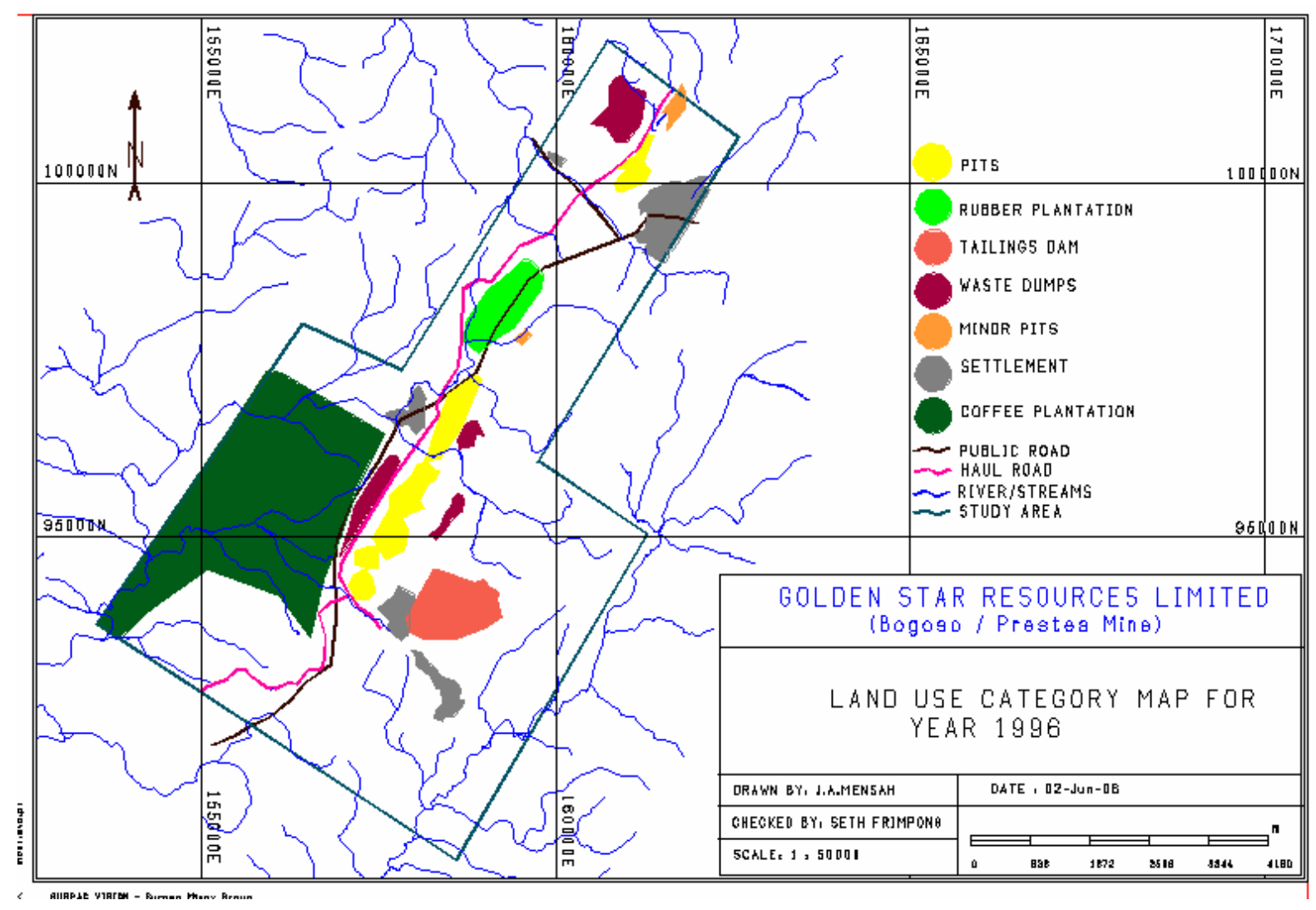

Fig. 4 Land Use Map of Study Area in 1996 at a Scale of 1: 50000 


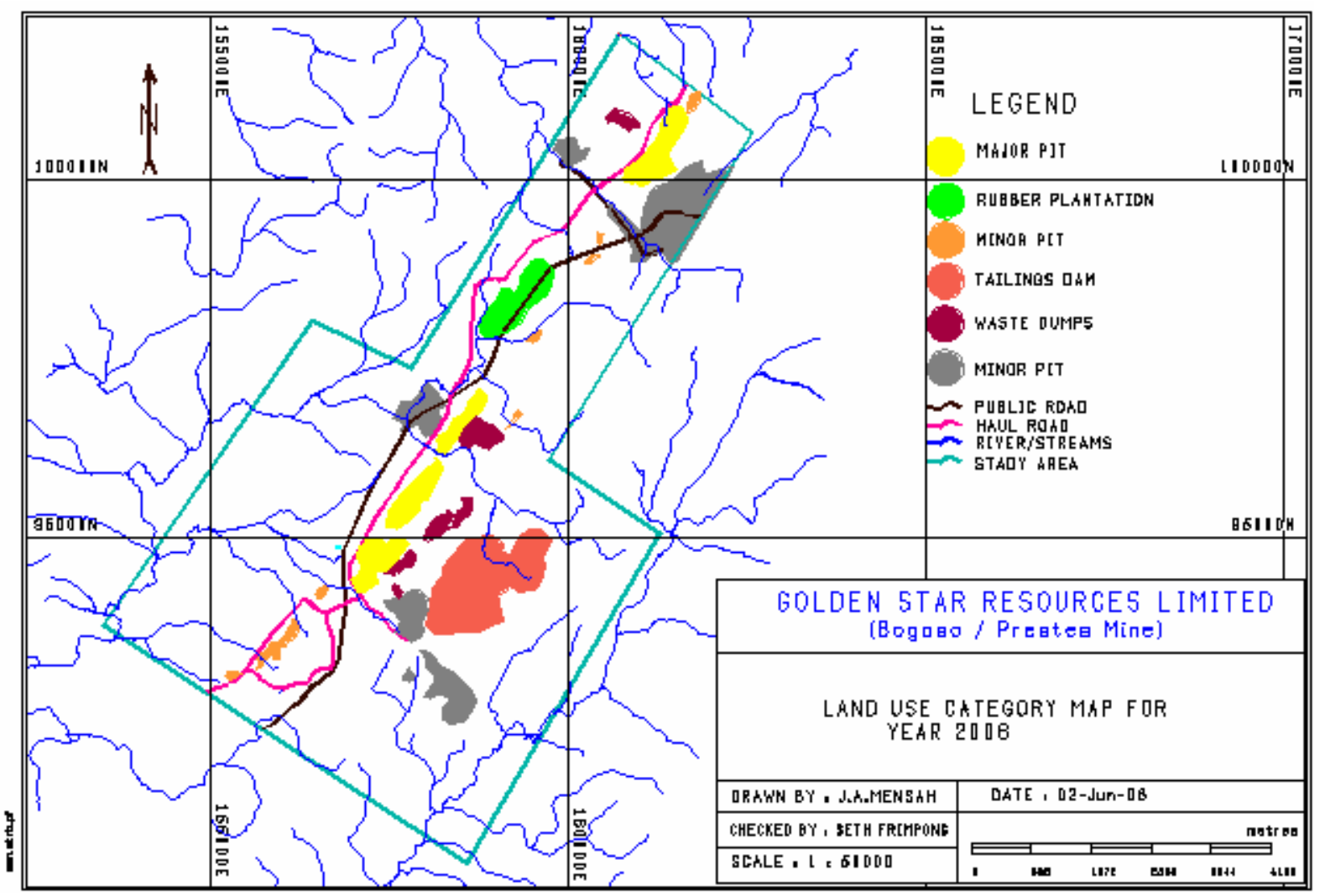

Fig. 5 Land Use Map of Study Area in 2006 at a Scale of 1: 50000

Table 1 Results of Data Validation of Land Use Categories

\begin{tabular}{|l|l|l|l|l|l|l|}
\hline \multirow{2}{*}{ Land Use Category } & \multicolumn{3}{|c|}{1996} & \multicolumn{3}{c|}{2006} \\
\cline { 2 - 8 } & Digitised & Surveyed & Diff. & Digitised & Surveyed & Diff. \\
\hline Chujah Waste Dump/ha & 25.970 & 25.9698 & 0.0002 & & & \\
\hline Tailings Dam (TSF1)/ha & & & & 63.572 & 63.5717 & 0.0003 \\
\hline Marlu-BogoNorth Pit/ha & & & & 36.140 & 36.1401 & 0.0001 \\
\hline Dumasi Village/ha & & & & 25.514 & 25.5138 & 0.0002 \\
\hline Public Road/km & 10.338 & 10.335 & 0.003 & & & \\
\hline
\end{tabular}

\subsection{Data Analysis}

Changes in land cover and use can be studied by means of various approaches and at several levels, depending on the available information. Two different approaches were used in this study namely: Estimation of Area Change and Analysis of Land Use Flows.

With regard to the observation of changes in land use, area balances present the first level of analy-

sing change. Changes in the area estimates are the

Table 2 Land Use Flow Matrix for the Bogosu-Prestea Concession

\begin{tabular}{|c|c|c|c|c|c|c|c|}
\hline YEAR 1996 & & & & & 5. SETTLEMENT & 6. ROADS & $\begin{array}{l}\text { TOTAL } \\
\text { LAND }\end{array}$ \\
\hline YEAR 2006 & LAND & PITS & PITS & DUMP & & & $\begin{array}{c}\text { AREA YR. } \\
1996\end{array}$ \\
\hline 1. AGRICULTURAL LAND & 3531.32 & 20.19 & 17.39 & 82.12 & 81.81 & 22.46 & 3755.30 \\
\hline 2. MAJOR PITS $(x>15 \mathrm{ha})$ & 17.39 & 76.22 & 0.00 & 0.00 & 0.00 & 0.00 & 93.62 \\
\hline 3. MINOR PITS $(x<15 \mathrm{ha})$ & 14.71 & 9.51 & 11.22 & 3.56 & 0.00 & 0.00 & 39.00 \\
\hline 4. MINE WASTE DUMP & 58.22 & 0.00 & 0.00 & 110.29 & 0.00 & 0.00 & 168.51 \\
\hline 5. SETTLEMENT & 0.00 & 0.00 & 0.00 & 0.00 & 135.00 & 0.00 & 135.00 \\
\hline 6. ROADS & 0.00 & 0.00 & 0.00 & 0.00 & 0.00 & 188.50 & 188.50 \\
\hline $\begin{array}{l}\text { TOTAL LAND AREA } \\
\text { YEAR } 2006\end{array}$ & 3621.64 & 105.93 & 28.62 & 195.97 & 216.81 & 210.97 & 4379.93 \\
\hline
\end{tabular}


core set of area statistics. Polygon areas of the individual land use categories were computed using ArcGIS software.

Flow analysis of land use offers a more detailed analysis of changes in land use and refer to the estimation of how a certain land use category expanded or reduced. Flows are analysed by means of matrices, where land use information obtained from different years are crossed. Table 2 shows the land use flow matrix of the area under investigation.

The diagonal cells in Table 2 show unchanged areas where the same areas in time have identical cover. The row cells explain which current cover classes (in year 2006) replaced the former cover (loss), while the columns describe the expense at which the new cover classes are established (gains). The flows, ie the conversion and modification of land cover categories reveal in a comprehensive way the evolution of land use in the study area. A focus on specific flows may reflect some underlying processes; for example; flow from agri- cultural to settlement may be due to urban-to-rural migration. It is also possible to link these flows to the pressures brought to bear on land. As such, these flow tables play an important role in the assessment of environmental impacts due to economic development (Haines-Young, 2000).

\section{Results and Discussions}

Table 3 shows that agricultural land decreased by $12.05 \%$ while mining land gained $6.77 \%$ between 1986 and 1996. Rural migration increased by $2.68 \%$ during the same period.

In Table 4 agricultural land decreased by $3.05 \%$ from 1996 to 2006 and during the same period, mining land increased by $0.67 \%$; showing a reduction in the rate of expansion of land use due to mining. This reduction may be attributed to environmental awareness which is being advocated by some Non-Governmental Organisations (NGO) in the Wassa West District. Rural migration increased by $1.87 \%$ between 1996 and 2006 .

Table 3 Analysis of Land Use Changes for 1986 and 1996

\begin{tabular}{|c|c|c|c|c|c|c|}
\hline \multirow[b]{2}{*}{ LAND USE } & \multirow{2}{*}{$\begin{array}{c}\text { YEAR } 1986 \\
\text { Hectares }\end{array}$} & \multirow{2}{*}{$\begin{array}{c}\text { YEAR } 1996 \\
\text { Hectares }\end{array}$} & \multirow[b]{2}{*}{$\begin{array}{l}\text { Net } \\
\text { change }\end{array}$} & \multicolumn{3}{|c|}{ PERCENTAGE (\%) } \\
\hline & & & & 1986 & 1996 & $\begin{array}{c}\text { Net } \\
\text { Change }\end{array}$ \\
\hline 1. AGRICULTURAL LAND & 4283.18 & 3755.30 & -527.88 & 97.79 & 85.74 & -12.05 \\
\hline 2. MAJOR PITS $(x>15 \mathrm{ha})$ & 0.00 & 93.62 & 93.62 & 0.00 & 2.14 & 2.14 \\
\hline 3. MINOR PITS $(x<15 \mathrm{ha})$ & 4.69 & 39.00 & 34.31 & 0.11 & 0.89 & 0.78 \\
\hline 4. WASTE DUMP & 0.00 & 168.51 & 168.51 & 0.00 & 3.85 & 3.85 \\
\hline 5. SETTLEMENT & 17.79 & 135.00 & 117.21 & 0.41 & 3.08 & 2.68 \\
\hline 6. $R O A D S$ & 74.28 & 188.50 & 114.22 & 1.70 & 4.30 & 2.61 \\
\hline TOTAL LAND AREA & 4379.94 & 4379.94 & 0.00 & 100.00 & 100.00 & 0.00 \\
\hline
\end{tabular}

Table 4 Analysis of Land Use Changes for 1996 and 2006

\begin{tabular}{|c|c|c|c|c|c|c|}
\hline \multirow[t]{2}{*}{ LAND USE } & \multirow{2}{*}{$\begin{array}{c}\text { YEAR } \\
1996 \\
\text { Hectares }\end{array}$} & \multirow{2}{*}{$\begin{array}{c}\text { YEAR } \\
\mathbf{2 0 0 6} \\
\text { Hectares }\end{array}$} & \multirow[b]{2}{*}{$\begin{array}{c}\text { Net } \\
\text { change }\end{array}$} & \multicolumn{3}{|c|}{$\begin{array}{c}\text { PERCENTAGE } \\
(\%)\end{array}$} \\
\hline & & & & 1996 & 2006 & $\begin{array}{c}\text { Net } \\
\text { Change }\end{array}$ \\
\hline 1. AGRICULTURAL LAND & 3755.304 & 3621.642 & -133.662 & 85.74 & 82.69 & -3.05 \\
\hline 2. MAJOR PITS $(x>15$ ha) & 93.622 & 105.934 & 12.311 & 2.14 & 2.42 & 0.28 \\
\hline 3. MINOR PITS $(x<15 \mathrm{ha})$ & 39.000 & 28.616 & -10.385 & 0.89 & 0.65 & -0.24 \\
\hline 4. MINE WASTE DUMP & 168.513 & 195.969 & 27.456 & 3.85 & 4.47 & 0.63 \\
\hline 5. SETTLEMENT & 134.995 & 216.808 & 81.813 & 3.08 & 4.95 & 1.87 \\
\hline 6. $R O A D S$ & 188.502 & 210.965 & 22.463 & 4.30 & 4.82 & 0.51 \\
\hline TOTAL LAND AREA & 4379.937 & 4379.934 & -0.003 & 100.00 & 100.00 & 0.00 \\
\hline
\end{tabular}


Fig. 6 shows a graph of percentage change in land use categories from 1986 to 2006. The figure reveals that agricultural land is by far the largest use to which land is utilised in the Bogosu-Prestea area. Agriculture consistently lost land to all the other land use categories who gained quite significantly. Mining gained a total of 530.84 ha by 2006 in terms of 105.934 ha for major pits, 28.616 ha for minor pits, mine waste dump 195.969 ha and 63.63 ha from 216.808 ha of settlements for mine residence and 136.690 ha from 210.965 ha of roads for mine roads registering a total of $12.1 \%$ due to mining land use of the study area.

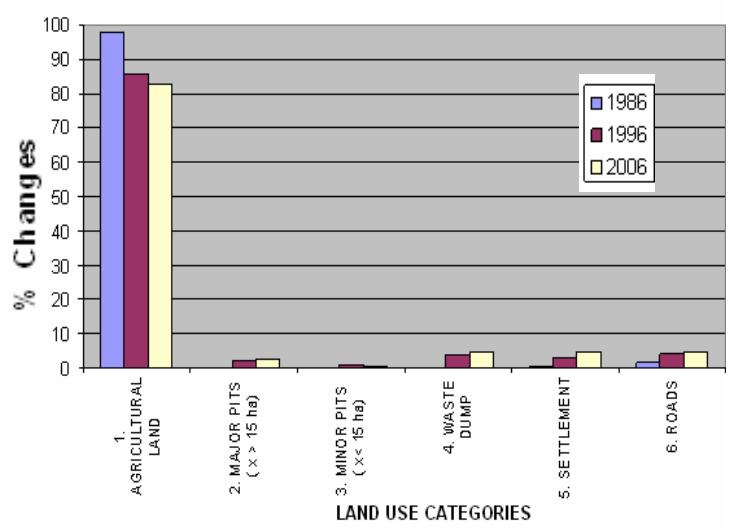

Fig. 6 Land Use Changes from 1986 To 2006.

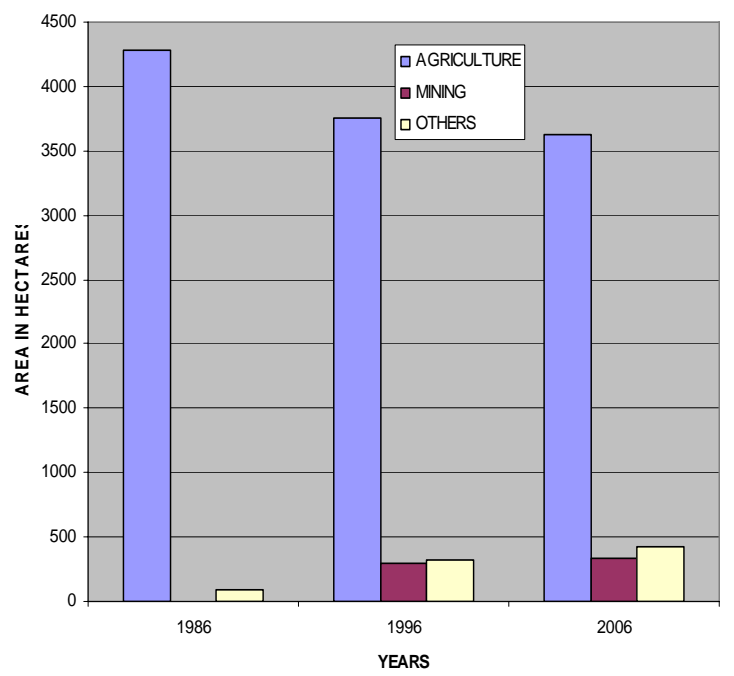

Fig 7 Land Use Changes Due to Mining as against Agriculture and Others

Fig. 7 shows that mining land was almost insignificant in 1986 but made significant gains in 1996 and 2006 .

The study revealed that agriculture is the main use to which land is put in the study area, and between 1986 and 2006, this decreased by 661.54 ha representing $15.45 \%$ reduction. The loss incurred by agricultural land was due to the conversion of
101.24 ha into major pits, 28.62 ha into minor pits, 195.97 ha into mine waste dump, 199.02 ha into settlement and 136.69 ha into roads.

Mining, continued to gain grounds, between 1986 and 1996, major pits covered 93.62 ha $(2.14 \%)$ of the study area and increased by additional 105.93 ha $(2.42 \%)$ in 2006. Likewise, Minor pits increased from 4.69 ha $(0.11 \%)$ to 39.00 ha $(0.89 \%)$ in the first period but decreased to 28.62 ha $(0.65 \%)$ in the second period. Mine waste dump occupied 168.51 ha $(3.85 \%)$ in the first period and increased to 195.97 ha $(4.47 \%)$ at the end of year 2006. This increase was as a result of expansion of the tailings storage facility. Settlement areas continued to grow in terms of land coverage over the years. There was an increase from 17.79 ha $(0.41 \%)$ in 1996 to 216.81 ha $(4.95 \%)$ at the end of 2006. This growth means that at the end of the 20 year period, settlement had increased about twelve times. Considering the main townships, part of Bogoso falls within the study area and increased in size from 14.4 ha $(0.33 \%)$ in 1986 to 112.6 ha $(2.57 \%)$ in 2006 . Dumasi and Kojokrom villages recorded an increase from 3.4 ha to 29.5 ha and zero to 11.1 ha respectively at the end of the study period.

Road network within the study area has also grown over the years. This growth is because of the construction of mining haul roads that link the public roads and serve as alternative access for public road users when public roads are not accessible.

The study revealed that mining land use occupies $12.1 \%$ (530.84 ha) of the study area. The various mining land use categories include the major and minor pits, mine waste dumps, mining haul roads, mine residence, offices and plant site. Public road occupies $1.7 \%$ (74.278 ha) and other settlements (Dumasi, Kojokrom and part of Bogoso township within the study area) take $3.5 \%$ (153.18 ha) of the land area.

\section{Conclusions}

Three general trends can be identified from the study:

- Decrease of agriculture land for the benefit of other land users;

- Increase of mining lands at the expense of agricultural land and

- Increase in rural migration as shown by the increase of settlement areas.

Agricultural land use decreased by 661.54 ha $(15.5 \%)$ over the 20 years. This lost was as a result of agricultural land being used for mining activities, construction of roads and expansion of settlements to accommodate the current increase in population within the community. The major question is whether this decrease is having negative or 
positive impact on the land considering the economic benefits from mining revenue enjoyed by the community and the country as a whole over the years? A cost benefit analysis may produce a solution to this question.

The study also revealed that land use due to mining stabilized between 1996 and 2006 after a rapid increase of 4.69 ha in 1986 to 530.84 ha in 1996. Also significant is that land use due to mining increased only by $0.67 \%$ between 1996 and 2006. If this trend continues, then mining land use may not increase significantly in the future. Continuous reclamation of mined-out land and/or underground development by GSRBPL may indeed reverse the trend of increasing mining land use.

Settlement areas have increased consistently from 17.79 ha in 1996 to 216.81 ha by the end of 2006 , showing the attraction of relevant professionals to the mining industry and exhibiting an urban-rural migration.

\section{References}

Bāhr, H. P. (2001), "Image Segmentation for Change Detection in Urban Environments", In: Remote Sensing and Urban Analysis, pp. 95-113.

Bannister, A and Raymond S. (1992), Surveying, Seventh Edition, Longman Scientific and Technical, England, pp. 249 -252.

Chen, Z., and Guevara, J. A. (1987), "Systematic Selection of Very Important Points (VIP) from Digital Terrain Models for Construc tion Triangular Irregular Networks", Pro ceedings of AutoCarto. ASPRS/ACSM, Falls Church, VA, pp. 50-56.

Donnay, J. P., Barnsley M. J. and Longley, P. A. (2001), Remote Sensing and Urban Analy sis, Taylor and Francis, London and New York, pp. 3-18.

Haines-Young, R. (2000), Accounting for Nature: Assessing Habitats in the UK Countryside, DETR, London, 134 pp.

Macleod, R. D. and Congalton, R. G. (1998), “A Quantitative Comparism of Change Detection Algorithms for Monitoring Eel grass from Remotely Sensed Data", Photo grametric Engineering and Remote Sens ing, 64 (3), pp. 207-216.

Singh, A. (1989), "Digital Change Detection Tech niques using Remotely-sensed Data", Inter national Journal of Remote Sensing, 10 (6), pp. 989-1003.

Sraku-Lartey, K. (1993), Annual Environmental Report on GSRBPL Operations, Report to EPA, Accra, Ghana, pp. 30- 33.

\section{Authors}

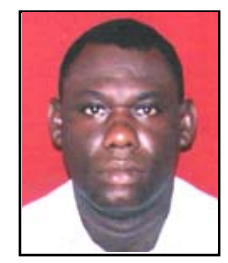

E. E. Duncan holds an MSc degree in Geomatics (Surveying) from the University of Glasgow, UK and a BSc degree in Geodetic Engineering from the Kwame Nkrumah University of Science and Technology, Kumasi, Ghana. He worked on a UNICEF mapping project of the Northern regions of Ghana in 1993 as a Surveyor. In 1996 he joined the University of Mines and Technology (UMaT), Tarkwa where he now lectures in GIS, GPS, Remote Sensing and Advanced Statistical Applications to Geomatics. He is affiliated to the Institution of Civil Engineering Surveyors, UK (ICES) and academic member of the Federation of International Surveyors (FIG). He is currently the Head of Geomatic Engineering Department.

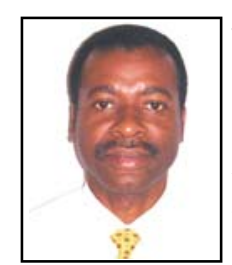

J. S. Kuma is an Associate Professor in Environmental Hydrogeology and Geophysics at the University of Mines and Technology (UMaT), Tarkwa. He was awarded a BSc (Hons) in Geology and Physics at the University of Ghana, Legon. He received the Pg Dip and MSc degrees in Geophysics at Delft, The Netherlands. Professor Kuma received a $\mathrm{PhD}$ in Water Resources Engineering from the University of Newcastle upon Tyne, England. $\mathrm{He}$ is currently actively involved in mine water hydrogeological research and water management issues.

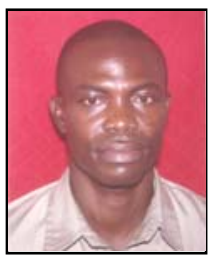

Seth Frimpong holds a Diploma in Mine Surveying from the University of Science and Technology School of Mines, Tarkwa, Ghana. He was a Senior Surveyor of Golden Star Resources Bogoso-Prestea Mine. He has 11 years of field experience in Surveying especially in the area of mineral exploitation, engineering and cadastral work. He is a member of the Ghana Institution of Surveyors. He recently completed his MSc at the University of Mines and Technology researching into Geographic Information Systems for assessing Land use changes He is currently a Chief Surveyor and Consultant with a mining company in Congo. 